\title{
Development of stem cell-based therapy for Parkinson's disease
}

\author{
Fabin Han*, Deborah Baremberg, Junyu Gao, Jing Duan, Xianjie Lu, Nan Zhang and Qingfa Chen
}

\begin{abstract}
Parkinson's disease (PD) is one of the most common neurodegenerative disorders of aging, characterized by the degeneration of dopamine neurons (DA neurons) in the substantial nigra, leading to the advent of both motor symptoms and non-motor symptoms. Current treatments include electrical stimulation of the affected brain areas and dopamine replacement therapy. Even though both categories are effective in treating PD patients, the disease progression cannot be stopped. The research advance into cell therapies provides exciting potential for the treatment of PD. Current cell sources include neural stem cells (NSCs) from fetal brain tissues, human embryonic stem cells (hESCs), induced pluripotent stem cells (iPSCs) and directly induced dopamine neurons (iDA neurons). Here, we evaluate the research progress in different cell sources with a focus on using iPSCs as a valuable source and propose key challenges for developing cells suitable for large-scale clinical applications in the treatment of PD.
\end{abstract}

Keywords: Parkinson's disease, Dopamine neuron, Neural stem cell, Human embryonic stem cells, Induced pluripotent stem cell, Induced dopamine neuron

\section{Introduction}

Parkinson's disease (PD) is one of the most common neurodegenerative disorders of aging, affecting about $1 \%$ of the population aged 60 years and older and $3-5 \%$ of the population above the age of 85 [1].

Clinically, patients with PD are characterized with both motor and non-motor symptoms. Motor symptoms, being far more noticeable, have typically been used in clinical diagnosis. The various disruptions in motor control include muscle rigidity, resting tremors, bradykinesia (slowness of movement), and postural instability, and typically appear when $60-80 \%$ of dopamine (DA) neurons in the substantia nigra are degenerated [2]. The reliable identification of non-motor symptoms is important as many non-motor symptoms, including depression, cognitive dysfuction, pain, and sleep disorders, precede the motor dysfunctions; not only is management of these symptoms important for quality of life, but early diagnosis of PD could also be key for effective treatment [3].

\footnotetext{
*Correspondence: fhan2013@126.com

Centre for Stem Cells and Regenerative Medicine, The Liaocheng People's

Hospital/Affiliated Liaocheng Hospital, Taishan Medical University, Shandong 252000, China
}

(C) 2015 Han et al. Open Access This article is distributed under the terms of the Creative Commons Attribution 4.0 International License (http://creativecommons.org/licenses/by/4.0/, which permits unrestricted use, distribution, and reproduction in any medium, provided you give appropriate credit to the original author(s) and the source, provide a link to the Creative Commons license, and indicate if changes were made. The Creative Commons Public Domain Dedication waiver (http://creativecommons.org/publicdomain/zero/1.0/) applies to the data made available in this article, unless otherwise stated. dopamine release, current treatments for PD include dopamine replacement drugs such as levodopa to increase dopamine levels, dopamine inhibitor carbidopa to reduce dopamine degradation in the peripheral blood $[4,5]$, and deep brain stimulation (DBS) to the nucleus subthalamicus [6]. Even though dopamine replacement drugs and DBS are effective in improving the symptoms of the patients, they cannot stop the disease progression. Moreover, current medications can cause the development of dyskinesia (involuntary muscle movements), effectively "overshooting" the clinical symptoms of PD. Recent research progress has provided treatment potential through replacing lost DA neurons using neural stem cells (NSCs) or fully differentiated DA neurons from fetal brain tissue, embryonic stem cells (ESCs), mesenchymal stem cells (MSCs) sourced from adults or fetuses, and induced pluripotent stem cells (iPSCs) reprogrammed from patients' somatic fibroblasts or blood cells. Much work has been done to adapt cells from various sources to potential clinical applications to improve treatments for neurodegenerative diseases including PD $[7,8]$. 


\section{Etiology and pathological mechanisms}

The causes of PD can be characterized as genetically susceptible genes and environmental toxic factors such as the pesticide rotenone and heavy metal manganese, which implicate oxidative damage and mitochondrial impairment leading to degeneration of dopamine neurons in PD [9-13]. The majority of PD cases are sporadic or idiopathic with unknown aetiology (80-90\% of PD cases), but a minority of cases (with estimates ranging from 10 to $20 \%$ of PD cases) are familial and can be linked to a particular monogenic mutation or associated to PD related genes. The twin studies have suggested that this finding can be explained by the fact that genetic factors do not play a major role in causing typical PD, particularly with regards to disease incidence after 50 years of age [14]. They suggested that genetic factors are only an important factor when the disease begins at or before the age of 50, a relatively rare occurrence. The most well-characterized mutation loci for early-onset autosomal recessive PD are PARK2(Parkin), PINK1, and PARK7, ATP13A2 whereas those for the autosomal dominant form of PD are SCNA and LRRK2. The susceptible genes associated with PD are Tau, Nurr1 and GBA. SCNA, which codes for alpha-synuclein, has been particularly well-studied; triplication of the locus has been associated with an aggressive form of PD that advances into cognitive impairment [15, 16]. There is ongoing debate as to the exact balance between the genetic and environmental factors mainly because the accuracy of clinical diagnosis of idiopathic PD has been disputed [17]. Some other reasons of the difficulties associated with assessing the disease etiology may be the result of inconsistent diagnostic criteria among heterogeneous populations of PD patients for study.
Pathologically, PD is involved in the degeneration and loss of dopamine (DA) neurons located in the substantia nigra of the the midbrain [18]. These DA neurons project to the basal ganglia (the striatum), which is heavily involved in motor control and function [19]. The loss of DA neurons is accompanied by lewy bodies and lewy neurites, which are mainly formed by insoluble aggregates of alpha-synuclein (coded by $S C N A$ ) and Tau protein and might hamper the survival and dendritic development of newborn neurons [20, 21]. The spread of lewy bodies in the brain causes motor symptoms accompanied by an intensification of the disease, including cognitive impairment that encompasses hallucinations, dementia, and speech difficulties $[22,23]$.

\section{Stem cell sources for the treatment of PD}

Several stem cell sources for the treatment of PD have been studied in the past decades and summarized in Fig. 1. Some studies used adult bone marrow-derived mesenchymal stem cells (BM-MSC) and olfactory ensheathing cells (OEC) [24-26], but these cells have limited ability to differentiate to dopamine neurons. Currently neural stem cells (NSCs) and dopamine neurons from fetal brain tissue, embryonic stem cells (ESCs), induced pluripotent stem cells (iPSCs) and directly induced dopamine neurons (iDA neuron) reprogrammed from autologous somatic cells have been widely studied to move these cells into bedside [27-29].

\section{NSCs and dopamine neurons from fetal brain tissue}

Neural stem cells (NSCs) were first reported in 1965 [30] and were described as granule cells with a high rate of proliferative activity in the cortex of brains. As a multipotent stem cell population, NSCs have neural potential and

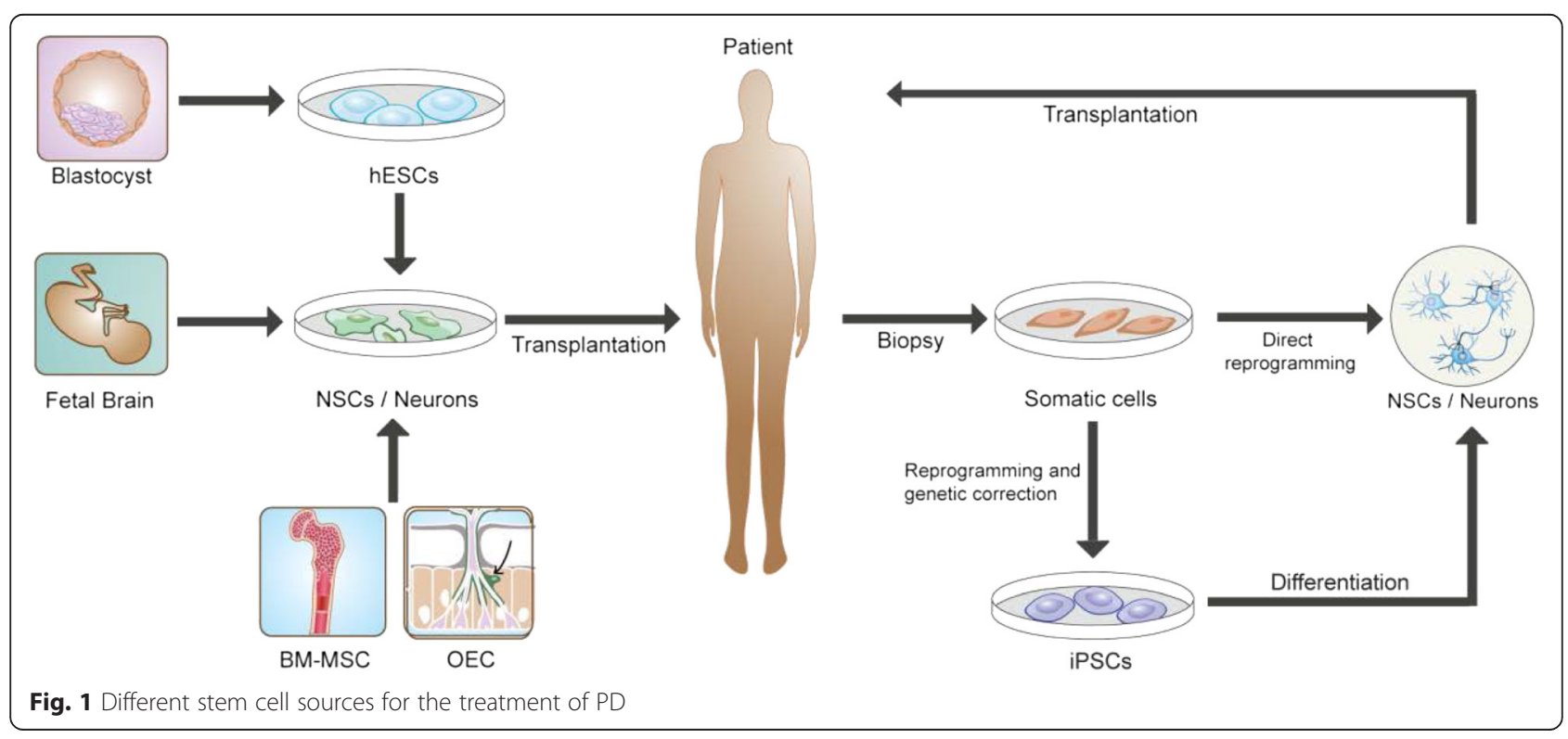


can differentiate into neurons, astrocytes and oligodendrocytes. NSCs can be also isolated from the other regions of fetal brains or from the hippocampus and subventricular zone (SVZ) of the adult mammalian brain, the areas where neurogenesis continues throughout the animal's lifespan [31, 32]. Since initial discoveries of NSCs, there have been many advances in the isolation, expansion, and differentiation of NSCs [33, 34]. Mouse and human NSCs transplanted into the rat brain migrate and differentiate in a site-specific manner. Moreover, Nishino et al. reported that these NSCs appear to differentiate preferentially into DA neurons in PD model rats with depleted host DA levels [35].

NSCs can be also induced to differentiate into specific neural cells in vitro prior to transplantation. Some homeodomain transcription proteins were isolated and selectively expressed in DA neural progenitors in the ventral midbrain, and it was found that $L m x 1 a$ and $M s \times 1$ function as lineage determinants triggering generation of DA neurons with midbrain identity. These factors were shown to initiate the differentiation of neural progenitor cells in chick embryos into midbrain DA neurons. These findings suggested that $L m \times 1 a$ and $M s \times 1$ play important roles in the specification and maturation of DA neurons. NSCs were differentiated into DA neurons via a five-step protocol similar to the culture conditions used to differentiate ESCs demonstrated the morphological characteristics of forebrain DA neurons. Kim et al. reported that overexpressing the transcription factor ASCL1 was able to regain neurogenesis from human neural progenitor cells and produced larger neurons with more neurites [36]. The identification of NURR1 mutation in PD patient suggested that NURR1 plays regulatory role in the development of DA neurons [37]. Forcing overexpression of Nurr1 was found to enhance the ability of mouse NSCs to differentiate into DA neurons and survive in vivo in PD rat models [38].

Animal studies showed that rodent and human fetal brain dopamine neurons transplanted to the midbrain of the 6-OHDA-lesioned rats survived well in the host brains and improved the motor defects of the PD rats [39]. Even though some studies reported limited recovery after transplanting fetal substantia nigra-derived cells into rat PD models, most found very promising results [40, 41]. Redmond et al. reported fetal ventral mesencephalic (VM) tissue transplanted to the 1-methyl-4-phenyl1,2,3,6-tetrahydropyridine (MPTP)-lesioned African Green Monkeys (AFG) survived well in the host brains, and all animals showed significant behavioral improvement in primate model of PD by 9 months post-transplantation [42]. Based on the animal studies, the first clinical trials began in Sweden in the late 1980s to transplant fetal dopaminergic neurons or tissue to PD patients in placebo-controlled protocols [43]. Subsequently, the clinical assessment protocols were modified to use the quantitative measurements of motor function, and several clinical trials were conducted to transplant human fetal brain-derived dopamine neurons to PD patients. In terms of behavioural and histological improvements, significant effects were found in these smallcase studies [44, 45]. Freed et al. performed double-blind, sham surgery-controlled study by selecting 40 patients with mean PD duration of 14 years and randomly dividing the patients into two groups of 20 patients each. The transplantation group was injected with fetal brain neural cells bilaterally whereas the control group received sham surgery. All the patients were evaluated at one year after transplantation based on the Unified Parkinson's Disease Rating Scale (UPDRS). As a result, significant improvements were found for younger PD patients at the age of 60 years old and younger whereas no significant improvements were found in older patients compared to the control group, implying that the therapeutic efficacy varied in certain subpopulations [45]. In general, clinical trials have had extremely variable functional outcome, though solid improvements need to be further determined by clinical and imaging evaluations $[46,47]$. Olanow et al. performed another double-blind controlled clinical trial with 34 severe PD patients for two years after transplantation. Patients were randomly received bilateral transplantation of fetal nigral neural cells as transplantation group or sham surgery as control group. Overall no significant therapeutic effects were in transplantation group versus the control group even though robust survival of dopamine neurons was observed at postmortem examination [48]. Interestingly in another double-blind study, 33 patients who were transplanted with fetal brain dopamine neurons were followed for 2 years and 15 of these patients were followed for 2 more additional years, a significant clinical improvement in UPDRS motor ratings and increase in putamen uptake on (18)F-fluorodopa ((18)F-FDOPA) PET indicated the viability of the fetal brain grafts in PD patients over the 4 year course of the study [49].

However, fetal brain tissue transplantation did not escape the side effect of dyskinesia, prevalent in more traditional levodopa treatments for PD. Olanow et al. found that $56 \%$ of patients into which fetal mesencephalic tissue was transplanted developed persistent dyskinesia after overnight withdrawal of dopaminergic medication [48] - far more than $15 \%$ of patients experiencing dyskinesia Freed et al. reported [45]. Though its exact prevalence may be contested, the recurrence of dyskinesia following neural transplantation has been well-documented [46, 50]. There is evidence that grafts containing serotonin neurons are more likely to have this detrimental effect and that dyskinesia may therefore be alleviated by ensuring a homogeneous cell population in transplantation $[51,52]$. In order to know the longterm results with fetal brain cell transplantation, three individual clinical trials were studied. One study found 
that transplanted fetal midbrain DA neurons survived without pathology after up to 14 years, suggesting the safety and feasibility of transplanted fetal brain cells for the treatment of PD [53], other two studies found that alpha-synuclein-positive lewy bodies eventually spread to the transplanted DA neurons in PD patients after 14 or 16 years of transplantation [54, 55]. These pathological changes suggest that PD can be an ongoing process.

The discrepancy may be the result of the difference between genetically and environmentally caused PD - a case of PD caused by genetic mutations would be an ongoing process, whereas a case of PD caused by environmental factors might be halted by the infusion of healthy cells. Therefore, it cannot be conclusively stated that DA neuron engraftment is a universally permanent treatment for PD; follow-up implantations may be required for optimal effectiveness. However, fetal midbrain cell transplantation did provide PD patients, on average, symptomatic improvements when compared to control groups, but it is not a recommendable therapy for PD unless significant improvements are made and issues regarding to consistency of improvements, recurrence of dyskinesia, and eventual spread of pathology are overcome. There is also, like all other allogeneic treatments, a risk of graft rejection - the fact that the midbrain tissue with which a patient is being treated has been sourced from a genetically distinct individual, causing immunogenic responses that must be repressed in the study $[56,57]$.

Moreover, the use of fetal primary tissue for PD treatment is not scalable, given the procurement difficulty and ethical concerns behind the use of NSCs from fetal brain tissues. Overall, the clinical trials with NSCs of fetal brains showed some improvements of symptoms and the survival of the transplanted cells in PD patients, but some results are controversial because of the limited cases or diversities of the PD patients [47]. Some of the clinical trials with fetal brain- derived NSCs or dopamine neurons are summarized in Table 1.

In order to further address the therapeutic effects of the transplanted NSCs for patients, a new multicenter and collaborative study of the European Union (TRANSEURO) was formed in 2010 to make new guidelines for clinical trials of fetal brain-derived cell therapy in PD. These include careful selection of patients: aged 30-68 at the time of inclusion, showing a good response to levodopa; early in the course of their disease (disease duration 2-10 years); systematic evaluation of cell preparation location of transplantation; clinical assessment standards; numbers of patients and; immunosuppression after transplantation and follow-up time. This study has completed the new clinical trial for more than 100 PD patients and results are in the analysis $[58,59]$. A significant clinical outcome was recently reported in two PD patients who were transplanted with fetal ventral mesencephalic cells and were followed up to 15 and 18 years post-transplantation. The motor improvement was observed in the first year and continued to 18 years after transplantation with discontinued levo-dopa replacement therapy [60].

\section{Human embryonic stem cells (hESCs)}

Embryonic stem cells (ESCs) are pluripotent, selfrenewing, and isolated from the inner cell mass of the pre-implantation blastocysts [61]. ESCs can therefore be differentiated into any kind of tissue cells, including

Table 1 Summary of the clinical trials using fetal brain cells for treatment of PD

\begin{tabular}{|c|c|c|c|c|c|c|}
\hline $\begin{array}{l}\text { No. of patients with cell } \\
\text { transplantation }\end{array}$ & $\begin{array}{l}\text { Follow-up } \\
\text { Time }\end{array}$ & $\begin{array}{l}\text { Symptom } \\
\text { improvement }\end{array}$ & $\begin{array}{l}\text { PET DA neuron } \\
\text { survival }\end{array}$ & $\begin{array}{l}\text { Side effect of } \\
\text { Dyskinesia }\end{array}$ & $\begin{array}{l}\text { Pathological lewy } \\
\text { body }\end{array}$ & $\begin{array}{l}\text { References And } \\
\text { publication year }\end{array}$ \\
\hline 1 & 12 months & $1 / 1$ & Yes & No & Not available & [43] \\
\hline 6 & $\begin{array}{l}10-72 \\
\text { months }\end{array}$ & $4 / 6$ & Yes & No & Not available & {$[77]$} \\
\hline 5 & $\begin{array}{l}18-24 \\
\text { months }\end{array}$ & $2 / 5$ & Yes & No & Not available & [36] \\
\hline $20 / 40$ & 3 years & $17 / 20$ & Yes & No & Not available & [45] \\
\hline $23 / 34$ & 24 months & $6 / 23$ & Yes & $56 \%$ dyskinesia & Not available & [48] \\
\hline 2 & 8 years & $2 / 2$ & Yes & $50 \%$ dyskinesia & Not available & [7] \\
\hline 5 & 9-14 years & Not available & Yes & Not available & Not available & [42] \\
\hline 1 & 14 years & $1 / 1$ & Yes & Dyskinesia & Lewy body & [55] \\
\hline 2 & $11-16$ years & Not available & Yes & Not available & Lewy body & [54] \\
\hline 33 & $2-4$ years & $45 \%$ & Yes & Not available & Not available & [8] \\
\hline 3 & $13-16$ years & Yes & Yes & Not available & Not available & [8] \\
\hline 2 & $\begin{array}{l}18 \text { and } \\
15 \text { years }\end{array}$ & $2 / 2$ & Yes & Not available & Not available & [24] \\
\hline
\end{tabular}


neural stem cells (NSCs), neurons and DA neurons. Mouse embryonic stem cells-derived NSCs, or fully differentiated neurons and dopamine neurons have been shown to have neuroprotective effects for the treatment of PD [62-64].

Human embryonic stem cells (hESCs) were first isolated by culturing inner cell mass cells with feeder cells of mouse embryonic fibroblasts (MEFs) [65]. In the past two decades, strategies have been developed to direct the hESC differentiation into the neural stem cells and neurons, in particular dopamine neurons for PD. Studies have shown the differentiation of hESCs into midbrain dopamine (DA) neurons by the application of specific patterning molecules that regulate midbrain development in vivo $[66,67]$. Transplantation of hESCs-derived neural precursor cells to the PD rats showed that grafted cells differentiated DA neurons in vivo and development of protocol for producing more DA neurons in vitro is required [68]. Moreover, Yan et al. developed protocols for generating specifically midbrain-like DA neurons from hESC-derived neuroepithelial cells by applying growth factors $\mathrm{SHH}$ and FGF8 in a specific sequence [69]. Their study suggested that early exposure to growth factor FGF8 and SHH instructs early precursors to adopt a region identity leading to differentiation of midbrain neuroepithelial cells. These hESC-derived dopamine neurons were able to improve the locomotive deficits of PD rat models, provided that grafted hESCderived dopamine neurons functioned in vivo [70]. In order to increase the efficiency of DA production from pluripotent stem cells, Chamber et al. developed a protocol by inhibiting SMAD signalling to enhance proliferation and survival of midbrain DA neurons from hESCs [71]. They reported that addition of Noggin and SB431542 for inhibiting SMAD signalling induces complete neural conversion of $>80 \%$ of hESCs under adherent culture conditions. Fasano et al. have reported that neurons in developmental default towards anterior regionalization, but may be shifted towards a midbrainlike identity by FGF8 or Wnt1 treatment [72]. In order to further improve complete conversion of hESCs to the dopamine neurons and decrease the teratoma potential in vivo, the same group developed a floor-plate-based method for generating hESCs-derived DA neurons in a differentiation medium containing activators of sonic hedgehog $(\mathrm{SHH})$ and canonical WNT signalling in vitro. They found that these DA neurons efficiently grew for more than 18 weeks and restored the amphetamineinduced rotation dysfunctions in vivo after being transplanted into 6-OHDA-lesioned rats and MPTP-lesioned rhesus monkeys [73]. Muramatsu et al. implanted NSCs derived from cynomolgus ES cells unilaterally in the putamen of neurotoxin- lesioned cynomolgus monkeys. They found that transplantation of NSCs derived from cynomolgus monkey ES cells can restore DA function in a primate model of PD [74]. Another group reported that using lentiviral vectors to express the key DA neuron-regulating gene, $L M X 1 A$, in hESCs produced ventral midbrain DA neurons of the A9 subtype which account for more than $60 \%$ of all neurons generated from $L M X 1 A$-transfected hESCs [75]. To determine the functional properties of hESC-derived DA neurons in vivo, hESC-derived midbrain dopamine neurons and fetal brain DA neurons were engrafted into rat models of PD. MRI and PET imaging analysis showed that grafted hESC-DA neurons survived, projected long neural branches, and played similar functions to improve the locomotive deficits of PD rats as fetal brain DA neurons, providing further preclinical evidence of hESCderived dopamine neurons for treatment of PD [76].

The major concerns to use stromal cell as feeder cells for culturing hESCs-derived cells for clinical purpose are that hESCs-derived cells contain some rodent cells and may increase the risk of immune rejections. To overcome this problem, some studies developed feeder-free culture system to use matrigels to replace the feeder cells [36, 77]. Schulz et al. moved towards clinical applicability by generating the neurons in a serum-free suspension system [78]. Vazin et al. were successful in replacing the PA6 stromal cells with growth factors SDF-1, PTN, IGF2, and EFNB1, which induced the differentiation of hESCs directly into TH-positive DA neurons [79]. Growth factors SHH and FGF8 were reported to substitute for PA6 stromal cells in generating DA cells after an initial induction step of differentiating hESCs into NSCs. They endeavoured to develop a scalable process applicable to the clinic and easily brought to Good Manufacturing Protocol (GMP) standards. Their culture protocols did not involve serum, but they made the important discovery that cells could be stored at each of the intermediate stages in their four-step process (propagation of ESC $\rightarrow$ generation of neural stem cells $(\mathrm{NSC}) \rightarrow$ induction of dopaminergic precursors maturation of dopaminergic neurons) without loss of functional ability, allowing cells to be transplanted at an appropriate time point in neural development [80].

Although hESCs can be efficiently differentiated into a large amount of DA neurons in vitro and showed solid functions to restore the motor dysfunctions in PD animal models, including mice, rats and non-human primates, clinical trials have not been performed for treating PD patients. The main problems with hESCs are: i) the phenotypic stability of hESC-derived dopamine neurons after transplantation, and ii) the worry about residual undifferentiated hESCs within the large numbers of cells that need to be injected for human therapy. The residual undifferentiated hESCs might indeed lead to tumor formation 
even if this is not observed anymore in rodent experiments. In addition, some ethical concerns and problems of immune rejection also limited the clinical applications of hESCs.

\section{Induced pluripotent stem cells (iPSCs)}

Earlier studies showed that differentiated somatic cells could be reprogrammed to an undifferentiated state using somatic cell nuclear transfer (SCNT). SCNT technology made the cloned lambs and cows available [81-83]. But generating patient-specific cells using this technique has not yet occurred [84, 85]. The successful generation of mouse iPSCs was first reported in Yamanaka lab in 2006 by lentiviral expression of four transcription factors: Oct3/ 4, Sox2, c-Myc, and Klf4 in mouse embryonic fibroblasts [86]. Soon afterwards, the Yamanaka lab, as well as other labs, used the human orthologs of these four transcription factors (OCT4, SOX2, c-MYC, KLF4), or OCT4, SOX2, NANOG and LIN28, to generate human iPSCs and patient- specific iPSCs with different diseases, including PD [86-88]. The implication of Oct3/4 and Sox2 was unsurprising as previous research defining their essential role in the propagation of undifferentiated ESCs in culture [89]. The roles of Klf4 and $c-M y c$ were promoting reprogramming of somatic cells. Later studies indeed showed that Oct3/4 and Sox 2 appear to be the only genes indispensable in generating iPSCs [90] whereas Klf4 and $c-M y c$ are disposable [91]. iPSCs share most of their characteristics with ESCs; they are pluripotent and self-renew indefinitely. However, they are generated via reprogramming the already-differentiated somatic cells of an organism back to their embryonic-like pluripotent state. Overcoming the problems associated with fetal NSCs and hESCs, iPSCs generated from patients will have wide applications for exploring the molecular mechanisms and cell-based therapy of neurodegenerative diseases [28, 86, 88, 92].

One of the major advantages of iPSCs over other cell types in clinical applications is that iPSCs can be generated from the cells of the individual being treated; the cultured cells will be autologous. This key trait of iPSCs theoretically minimizes the risk of rejection and enhances their integration into the brain tissues of patients with PD. Moreover, the ethical issues of using aborted fetuses as a cell source are circumvented. Once reprogrammed into iPSC state, the iPSCs can be systematically exposed to specific factors that direct the cells to differentiate into a specific lineage (such as NSCs or DA neurons) $[93,94]$. Much research has been done to improve the generation, differentiation, and potential clinical applications of iPSCs, with particular efforts made to bring these therapeutic cells to GMP (Good Manufacturing practice) standards such that they can be translated to the clinic for treatment of neurodegenerative diseases such as PD [95]. iPSCs have also been used in drug screening and discovery and as a disease model to study the molecular mechanisms of the disease [96].

To determine the clinical potential of iPSCs-derived cells, the therapeutic effects of mouse iPSCs were studied by transplanting the iPSCs into rat brains [97]. They found that grafted iPSCs matured into midbrain-like dopamine neurons, resulting in behavioural improvements in rat PD models. In other studies, human iPSCsderived neurons or neural stem cells showed therapeutic effects in rat and monkey PD models [9, 98-100]. Even though many studies indicated the iPSCs induced improvement of motor function in animal PD models, no clinical trials have been reported using human iPSCs for the treatment of PD patients. Because the integration of viral vectors and transgenes in the genome of iPSCs from patients may affect their differentiation potential or induce malignant transformation, Jaenish et al. derived PD patient-iPSCs free of transgenes using Crerecombinase to excise the reprogramming factors. These patient-iPSCs showed a global gene expression profile more closely related to hESCs and hiPSCs carrying the transgenes [101]. DA neurons from the iPSCs with the LRRK2 mutation (G2019S) were found to be sensitive to oxidative stress and have increased expression of key oxidative stress-response genes and $\alpha$ - synuclein aggregation [102]. After correction of the LRRK2 G2019S mutation in iPSCs, the degenerated DA neurons was rescued, supporting the idea that LRRK2 mutation plays important roles in the pathogenesis of PD [103]. Emborg et al. reported that autologous transplantation of rhesus monkey iPSC-derived neural progenitors to the brain of MPTP-induced hemiparkinsonian rhesus monkeys survived well and differentiate into neurons, astrocytes, and myelinating oligodendrocytes [104]. Isacson et al. used stromal feeder cell-based protocol to differentiate the virus-free PD-iPS cells into DA neurons and transplanted the DA neurons into the 6-OHDA- lesioned rats. They found that these DA neurons survived and mediated functional improvements in PD rats by reducing apomorphine-induced rotational asymmetry [98]. The same group producted the midbrain dopamine neurons derived from the cynomolgus monkey (CM) iPSC and autologously transplanted into the MPTP-lesioned CMs. They found that autologous iPSC dopamine neurons can provide long-term functional recovery and transplanted cells survive for up to 2 years and reinnervate the host brain [105]. Recently, we worked all the way from isolation of skin fibroblasts of PD patients and control individuals, to the generation of iPS cells by retrovirus-mediated expression of OCT4, SOX2, c-MYC and KLF4, to the differentiation of iPS cells to neural stem cells (NSC) and DA neurons, and finally to the transplantation of the iPS cells-derived NSCs to the striatums of the 6-OHDA-induced PD rats. We found 
that iPS cells carrying the transgenes can also be differentiated into the DA neurons in vitro as well as survive and be differentiated into neurons and DA neurons in PD rats. The grafted iPS cells-NSCs significantly improved the motor defects of PD rats from the 4th week to the 16th week [9]. Our results showed that iPS cells carrying the transgenes can be differentiated into DA neurons in vitro and in vivo; however, the differentiation efficiency of neurons and DA neurons need to be further improved by modifying the cell culture protocols, including growth factors and iPS cells together for transplantation, or increasing the dose of immune-suppressive agents to reduce the immune-rejection against the human-derived cells.

Research advances have been made towards improving effectiveness of iPSC generation in the absence of c-Myc. Inhibitors of DNA methyltransferase, histone deacetylase, and valproic acid (VPA) were reported to improve reprogramming efficiency, particularly improving efficiency by two orders of magnitude - up to $10 \%$ - without induction of c-Myc. Stadtfeld et al. used non- integrating, replication-incompetent adenoviruses expressing the classic four transcripton factors to reprogram mouse liver cells into iPSCs [106]. Okita et al. developed a protocol by which repeated transfection of plasmids containing the appropriate genes (one containing the complementary DNAs of Oct3/4, Sox2, and Klf4; the other, $c-M y c)$ into embryonic fibroblasts, resulting in iPSC cells [107]. This protocol was adapted for use in human cells by Kaji et al. [108], though the transposon piggyBac was utilized in the process, with the risk of residual sequences and chromosomal distruptions. A further approach to iPSC generation has been the use of nonintegrating episomal vectors, which allows the derivation of iPSCs that are completely free of vector and transgene sequences [109]. The DNA vector-free, direct protein transduction system was also proposed to generate iPSCs to eliminate potential risks associated with chromosomal integrations and mutations [110]. Consistent similarity in cellular and differentiation properties were found between hiPSCs from integrating and non-integrating reprogramming factors [7] . But one study showed that protein-based reprogramming of cells into hiPSCs resulted in cells that behaved most similarly to hESCs, without showing obvious exogenous reprogramming gene expression [111].

A major limitation for current ES/iPS cell differentiation protocols is the lack of clinical-grade DA neurons with a stable phenotype, the A9-subtype ventral midbrain DA neurons. To overcome this problem, Isacson et al. have developed an efficient differentiation and sorting strategy for DA neurons from both human ES/iPS cells. The NCAM (+) /CD29 (low) enriched VM DA neurons were sorted from pluripotent stem cell- differentiated neural cells. Molecular studies showed that the sorted neurons were positive for FOXA2/TH and $\mathrm{EN} 1 / \mathrm{TH}$ and had increased expression levels of FOXA2, LMX1A, TH, GIRK2, PITX3, EN1, and NURR1, indicating that the sorted neural cells are DA neurons. After transplantation, this population of iPSC-derived DA neurons was able to restore motor function of 6-OHDAlesioned rats. The transplanted sorted cells were found to be integrated in the rat brain tissue with $\mathrm{TH}$ $+/$ hNCAM+ staining in the host striatum. This study provided experimental evidence for the feasibility and safety of iPSC-derived cell therapies in the future [99].

Another issue is the similarities and differences between iPSCs and ESCs. Several groups succeeded in generating both mouse iPSCs and human iPSCs epigenetically and developmentally identical to ESCs through improvement of end points for the reprogramming process [112, 113]. Modifications have also been made in a bid to reduce the mutagenic potential of the retroviruses and lentiviruses being used. For example, the reactivation of the $c-M y c$ retrovirus particularly increases the risk of mutations, hence increasing the posibility of tumerogenicity [114]. Substituting Nanog and Lin28 for Klf4 and c-Myc [88] has been found to be one way to reduce this risk. However, eliminations of $c-M y c$ from the protocol resulted in far lower efficiency of iPSC formation. This suggests that the role of $c-M y c$ is to accelerate proliferation or otherwise enhance the speed of events establishing pluripotency, while not being necessary in the establishing of pluripotency itself [115]. Though the generated iPSCs were very similar to ESCs in morphology, growth properties, and differentiation into different germ layers, differences between ESCs and iPSCs were detected; this may be caused by using different iPSC lines [116]. In order to know the similarity and difference between iPSCs and hESCs at the molecular levels, Koyanagi-Aoi et al. analysed 49 human iPSC lines and $10 \mathrm{hESC}$ lines. They found that only two iPSC lines have varied gene expression and DNA methylation. In vitro neural differentiation was compared between 40 human iPSC lines and 10 hESC lines, and only 7 iPSC lines had some undifferentiated cells after neural differentiation and formed teratoma when transplanted into mouse brains. This study indicated that iPSCs are very similar to hESCs with some difference in the specific iPSC lines [117].

Once again, it is important to note that such protocols must be adapted to a xeno-free, scalable system for the clinic. Rodriguez-Piza et al. [118] reprogrammed human fibroblasts to iPSCs under strict xeno-free conditions, providing a path to GMP applicability. Chen et al. described a suspension culture system for hESCs which was adapted by O'Brien [119] and Laslett [120] for use in hESCs and hiPSCs (reviewed by Serra et al. [121]). Such systems allowed long-term culture while retaining 
normal karyotype, appropriate marker expression, and pluripotency, and moreover allowed cryopreservation of cells. The future direction of pluripotent stem cell generation for clinical use lies in the use of such suspension culture bioreactors, with the added challenge of maintaining quality-control of the derived cells. To reduce the effects of transgenes on functions of the iPS cells, several labs developed methods to use two or three factors to generate iPS cells. Deng et al. reported that iPS cells can be generated from mouse embryonic and adult fibroblasts by a single factor of OCT4 in combination with small molecules of VPA, CHIR 99021, and TGF- $\beta$ inhibitor [91]. A recent study indicated that the derivation of rhesus monkey naive iPSCs can be obtained with only small molecules, omitting the OCT4, providing a valuable cell source for use in preclinical research and disease modeling [122].

\section{Directly induced dopamine neurons (iDA neurons)}

Though iPSCs give great potentials to the cell-based therapy for $\mathrm{PD}$, the complicated procedures for generation, characterization, and differentiation into the DA neurons push the researchers to find other convenient methods to obtain DA neurons. In addition, the human iPSC-derived neural stem cells or dopamine neurons may contain the undifferentiated cells which can cause tumor formation and limit their clinical application. Direct generation of iDA cells from somatic cells might have significant implications for understanding critical processes for neuronal development in vitro disease model and cell replacement therapies. One of the other approaches is to directly induce the fibroblasts of PD patients to DA neurons (iDA neurons). Recent studies have reported the success of generating DA neurons by directly reprogramming the fibroblasts with different combinations of transcription factors Mash1 (Ascl1), Nurr1 (Nr4a2), Lmx1a, Ngn2, Sox2, and Pitx3 [123-125].

Caiazzo et al. first reported the production of the dopamine neurons directly reprogrammed from human and mouse fibroblasts. They identified three transcription factors, Mash1 (Ascl1), Nurr1 (Nr4a2) and Lmx1a, which are able to directly convert mouse and human fibroblasts to functional dopaminergic neurons. They have showed that the directly converted dopamine neurons have electro-physiological activity similar to the dopamine neurons [123]. Kim et al. reported that lentiviral expression of eight different transcription factors of Acsl1, Mytl1, Brn2, Lmx1a, Lmx1b, Nurr1, Pitx3 and EN1 in mouse fibroblasts is sufficient to induce midbrain dopaminergic neurons-like cells expressing dopamine neuron marker of Pitx3. They found that two of the eight transcription factors, Acsl1 and Pitx3 are necessary for inducing fibroblast to dopamine neurons. Importantly these directly reprogrammed DA neurons function in mouse model of PD [126]. Kim et al. combined the transcription factors of which induced the fibroblasts to the neural progenitor cells (NPCs) and the culture environment containing SHH and FGF8 to induce the dopaminergic neuronal progenitors which can produce the dopamine neurons expressing $\mathrm{TH}$ and releasing dopamine [125].

Since most direct reprogramming methods are using lentiviral vectors to express the genes related to development of DA neurons, these transgenes may integrate into the genome of the iDA neurons and produce mutagenesis in iDA neurons. In addition, the fibroblasts from PD patients may also carry the genetic mutations of the genes such as SNCA, Parkin, LRRK2, and GBA as we discussed in iPSCs. These issues can cause safety concerns for clinical use of the directly reprogrammed DA neurons. However, the research advancement will eventually overcome these issues and bring these cells to clinical trials for PD.

\section{Future aspects and challenges for cell-based therapy of PD}

As we discussed above, the NSCs and DA neurons from fetal brain and hESCs are not suitable for clinical use because of their immune-rejections and ethical issues. The availability of iPSCs and iDA neurons paved the road for autologous cell-based therapy of PD. A clinical trial to use iPSCs for the treatment of eye disorders has been initiated in Japan. However, several aspects of iPSCs need to be resolved before they go to clinical use. These include low yields of DA neurons, genetic and epigenetic abnormalities, and the safety of iPSC-derived cells.

\section{Low yield}

Though low yields of fully reprogrammed cells are a recurring problem, this is by no means an inherent property of iPSC generation, and there will continue to be yield improvements in the future. The original yields of $0.05 \%$ have been increased by various factors, such as the addition of VPA and other chemicals in generating iPSCs [127]. Yamanaka et al. proposes the stochastic model, under which most or all differentiated cells have the potential to become iPSCs. Indeed, though iPSCs are typically generated from fibroblast cells, they have been generated from a wide array of cells from all three cell lines (mesodermal, endodermal, and ectodermal). Stadtfeld et al. [101] used liver cells; Aoi et al. [128] used stomach and liver cells; Aasen et al. [129] used human hair cells, indicating that cells can theoretically be sourced from virtually anywhere on the adult human, with varying yields across experiments. In fact, Aasen et al. found that keratinocytederived iPSCs from adult human hairs were indistinguishable from ESCs and generated with a 100-fold increase in efficiency compared to human fibroblast reprogramming 
[129]. In any case, future avenues must include comparisons between method efficiencies, with the goal of optimizing protocols for maximum cell yield of iPS cells.

\section{Genetic and epigenetic abnormalities}

There remain concerns regarding epigenetic memory in iPSCs and iDA neurons towards a cell fate related to their donor source and otherwise maintaining a reprogramming signature after differentiation [130, 131]. The lentivirus or retrovirus-mediated reprogramming methods should be replaced by non-integrating vectors to express the reprogramming genes or combine with small molecules for the generation of clinical applicable iPS cells [132]. Some iPSCs from PD patients may also contain gene mutations such as point mutations, chromosomal structure variations, gene duplications, and deletions in the genes of SNCA, Parkin, LRRK2, GBA or others [103, 133-137]. The cells derived from iPSCs with genetic mutations are not suitable for direct transplantation as the functions of cells are affected by the genetic mutations. Several protocols have been developed to correct the mutation in PD patient-derived iPSCs. It was reported that the SNCA mutation (A53T) in iPSCs could be repaired by a zinc-finger nuclease (ZFN)-mediated nuclease approach and the ability to differentiate into dopaminergic neurons was not affected by genetic correction of the A53T mutation in the patient-derived iPSCs. PCR genotyping and sequencing analysis confirmed the correctly repaired patient-derived iPSC lines [137]. A recent study showed that the LRRK2 G2019S mutation in iPSCs was corrected and the LRRK2 mutation correction produced phenotype rescue in differentiated neurons [103].

\section{Safety and purity}

To obtain iPSC-derived NSCs or DA neurons for the treatment of $\mathrm{PD}$, it is required that the residues of undifferentiated iPSCs should be less than $1 \%$ to avoid teratoma formation after transplantation. Approaches have been developed to sort the iPSC-derived cells with FACS or other non-invasive magnetic selection. In addition, the cell culture should be carried in feeder-free conditions to avoid the contamination of animal sources. Currently, murine-derived feeder cells are widely used to maintain hESCs and hiPSCs. Also, culture medium containing fetal bovine serum (FBS) is normally used for the culture of these feeder cells. This will cause the allogenic cell contamination of the iPSC-derived cells. A recent study developed a feeder-free system to culture the hESCs and iPSCs in the StemFit ${ }^{\text {tw }}$ medium, taking a big step toward making clinically-applicable GMP-standard cells [138].

\section{Onwards to the clinic: conclusion}

Cell replacement therapy is a promising avenue for the treatment of PD and other neurodegenerative disorders. The use of all cell sources derived - fetal NSCs, ESCs , iPSCs and iDA neurons - is fraught with ethical, logistical, and safety concerns. However, scientific research is making great progress in the development and characterization of iPSC derived cells for PD. iPSCs and their derivatives injected into animal models have shown promise in treatment of disorders such as PD; however, iPSCs have not been used in clinical trials for PD. There are some limitations/disadvantages associated with iPSCs. A relevant therapeutic progenitor or mature cell type may be identified and grafted in such treatments; in the case of $\mathrm{PD}$, the options are, of course, iPSC-derived NSCs and iPSC-derived DA neurons. Theoretically, these two should act just like their non-iPSC derived counterparts -in actuality, because of the concerns mentioned above, the unique iPSC heritage of such cells sometimes poses its own unique set of problems.

Pre-clinical studies on viability might also be necessary to establish the scope of the treatment. iPSCs would not be moved to clinical trials at least until iPSCs are better understood and efficient and safe methods for reprogramming and gene correction are developed. The pace of progress will no doubt continue to speed along in the years to come, and it is therefore quite likely that within our lifetime we will witness the jump from dish to clinic.

\section{Competing interests}

The authors declare that the research was conducted in the absence of any commercial or financial relationships that could be construed as a potential conflict of interest.

\section{Authors' contributions}

Centre for Stem Cells and Regenerative Medicine, The Liaocheng People's Hospital/Affiliated Liaocheng Hospital, Taishan Medical University, Shandong 252000, China. All authors contributed to the preparation of this manuscript.

\section{Acknowledgements}

This work was supported by National Natural Science Foundation of China (NSFC 81271251) and The Science and Technology Developmental Fund of Shandong Province, China (2012GGA15049).

Received: 18 May 2015 Accepted: 24 August 2015

Published online: 03 September 2015

\section{References}

1. de Rijk MC, Launer LJ, Berger K, Breteler MM, Dartigues JF, Baldereschi M, et al. Prevalence of Parkinson's disease in Europe: a collaborative study of population-based cohorts. Neurologic Diseases in the Elderly Research Group. Neurology. 2000;54(11 Suppl 5):S21-3.

2. Cheng $\mathrm{HC}$, Ulane CM, Burke RE. Clinical progression in Parkinson disease and the neurobiology of axons. Ann Neurol. 2010;67(6):715-25. doi:10.1002/ana.21995.

3. Chaudhuri KR, Healy DG, Schapira AH. Non-motor symptoms of Parkinson's disease: diagnosis and management. Lancet Neurol. 2006;5(3):235-45. doi:10.1016/S1474-4422(06)70373-8.

4. Olanow CW, Watts RL, Koller WC. An algorithm (decision tree) for the management of Parkinson's disease (2001): treatment guidelines. Neurology. 2001;56(11 Suppl 5):S1-88. 
5. Fahn S, Oakes D, Shoulson I, Kieburtz K, Rudolph A, Lang A, et al. Levodopa and the progression of Parkinson's disease. N Engl J Med. 2004;351(24):2498-508. doi:10.1056/NEJMoa033447.

6. Limousin P, Pollak P, Benazzouz A, Hoffmann D, Le Bas JF, Broussolle $E$, et al. Effect of parkinsonian signs and symptoms of bilateral subthalamic nucleus stimulation. Lancet. 1995;345(8942):91-5.

7. Chou BK, Mali P, Huang X, Ye Z, Dowey SN, Resar LM, et al. Efficient human iPS cell derivation by a non-integrating plasmid from blood cells with unique epigenetic and gene expression signatures. Cell Res. 2011;21(3):518-29. doi:10.1038/cr.2011.12.

8. Buttery PC, Barker RA. Treating Parkinson's disease in the 21st century: can stem cell transplantation compete? J Comp Neurol. 2014;522(12):2802-16. doi:10.1002/cne.23577.

9. Han F, Wang W, Chen B, Chen C, Li S, Lu X, et al. Human induced pluripotent stem cell-derived neurons improve motor asymmetry in a 6-hydroxydopamine-induced rat model of Parkinson's disease. Cytotherapy. 2015;17(5):665-79. doi:10.1016/j.jcyt.2015.02.001.

10. Costello S, Cockburn M, Bronstein J, Zhang X, Ritz B. Parkinson's disease and residential exposure to maneb and paraquat from agricultural applications in the central valley of California. Am J Epidemiol. 2009:169(8):919-26. doi:10.1093/aje/kwp006.

11. Lesage S, Brice A. Parkinson's disease: from monogenic forms to genetic susceptibility factors. Hum Mol Genet. 2009;18(R1):R48-59. doi:10.1093/hmg/ddp012.

12. Chen ML, Lin CH, Lee MJ, Wu RM. BST1 rs11724635 interacts with environmental factors to increase the risk of Parkinson's disease in a Taiwanese population. Parkinsonism Relat Disord. 2014;20(3):280-3. doi:10.1016/j.parkreldis.2013.11.009.

13. Lucchini RG, Martin CJ, Doney BC. From manganism to manganeseinduced parkinsonism: a conceptual model based on the evolution of exposure. Neuromolecular Med. 2009;11(4):311-21. doi:10.1007/s12017009-8108-8.

14. Tanner CM, Ottman R, Goldman SM, Ellenberg J, Chan P, Mayeux R, et al. Parkinson disease in twins: an etiologic study. JAMA. 1999;281(4):341-6.

15. Polymeropoulos MH, Lavedan C, Leroy E, Ide SE, Dehejia A, Dutra A, et al. Mutation in the alpha- synuclein gene identified in families with Parkinson's disease. Science. 1997;276(5321):2045-7.

16. Marques O, Outeiro TF. Alpha-synuclein: from secretion to dysfunction and death. Cell Death Dis. 2012;3:e350. doi:10.1038/cddis.2012.94.

17. Savitt JM, Dawson VL, Dawson TM. Diagnosis and treatment of Parkinson disease: molecules to medicine. J Clin Invest. 2006;116(7):1744-54. doi:10.1172/JCl29178.

18. Damier P, Hirsch EC, Agid Y, Graybiel AM. The substantia nigra of the human brain. II. Patterns of loss of dopamine-containing neurons in Parkinson's disease. Brain. 1999;122(Pt 8):1437-48.

19. Obeso JA, Rodriguez-Oroz MC, Rodriguez M, DeLong MR, Olanow CW. Pathophysiology of levodopa-induced dyskinesias in Parkinson's disease: problems with the current model. Ann Neurol. 2000;47(4 Suppl 1):S2232. discussion S-4.

20. Gibb WR, Lees AJ. The relevance of the Lewy body to the pathogenesis of idiopathic Parkinson's disease. J Neurol Neurosurg Psychiatry. 1988;51(6):745-52

21. Dawson TM, Ko HS, Dawson VL. Genetic animal models of Parkinson's disease. Neuron. 2010;66(5):646-61. doi:10.1016/j.neuron.2010.04.034.

22. Lees AJ, Hardy J, Revesz T. Parkinson's disease. Lancet. 2009;373(9680):2055-66. doi:10.1016/S0140-6736(09)60492-X.

23. Aarsland D, Andersen K, Larsen JP, Lolk A, Nielsen H, Kragh-Sorensen P. Risk of dementia in Parkinson's disease: a community-based, prospective study. Neurology. 2001;56(6):730-6.

24. Khoo ML, Tao H, Meedeniya AC, Mackay-Sim A, Ma DD. Transplantation of neuronal-primed human bone marrow mesenchymal stem cells in hemiparkinsonian rodents. PLoS One. 2011;6(5):e19025. doi:10.1371/ journal.pone.0019025.

25. Blandini F, Cova L, Armentero MT, Zennaro E, Levandis G, Bossolasco P, et al. Transplantation of undifferentiated human mesenchymal stem cells protects against 6-hydroxydopamine neurotoxicity in the rat. Cell Transplant. 2010;19(2):203-17. doi:10.3727/096368909X479839.

26. Shukla S, Chaturvedi RK, Seth K, Roy NS, Agrawal AK. Enhanced survival and function of neural stem cells-derived dopaminergic neurons under influence of olfactory ensheathing cells in parkinsonian rats. J Neurochem. 2009;109(2):436-51. doi:10.1111/j.1471-4159.2009.05983.x.
27. Meyer AK, Maisel M, Hermann A, Stirl K, Storch A. Restorative approaches in Parkinson's disease: which cell type wins the race? Neurol Sci. 2010;289(1-2):93-103. doi:10.1016/j.jns.2009.08.024

28. Han F. The applications of the induced pluripotent stem cells in studying the neurodegenerative diseases. Chinese Journal of Cell Biology. 2012;34(5):13.

29. Tsunemoto RK, Eade KT, Blanchard JW, Baldwin KK. Forward engineering neuronal diversity using direct reprogramming. EMBO J. 2015;34(11):1445-55. doi:10.15252/embj.201591402

30. Altman J, Das GD. Post-natal origin of microneurones in the rat brain. Nature. 1965:207(5000):953-6

31. Doetsch F, Caille I, Lim DA, Garcia-Verdugo JM, Alvarez-Buylla A. Subventricular zone astrocytes are neural stem cells in the adult mammalian brain. Cell. 1999;97(6):703-16.

32. Taupin P, Gage FH. Adult neurogenesis and neural stem cells of the central nervous system in mammals. J Neurosci Res. 2002;69(6):745-9. doi:10.1002/jnr.10378.

33. Svendsen CN, Caldwell MA, Ostenfeld T. Human neural stem cells: isolation, expansion and transplantation. Brain Pathol. 1999;9(3):499-513.

34. Kallur $T$, Darsalia $V$, Lindvall $O$, Kokaia Z. Human fetal cortical and striatal neural stem cells generate region-specific neurons in vitro and differentiate extensively to neurons after intrastriatal transplantation in neonatal rats. J Neurosci Res. 2006;84(8):1630-44. doi:10.1002/jnr.21066

35. Nishino H, Hida H, Takei N, Kumazaki M, Nakajima K, Baba H. Mesencephalic neural stem (progenitor) cells develop to dopaminergic neurons more strongly in dopamine-depleted striatum than in intact striatum. Exp Neurol. 2000;164(1):209-14. doi:10.1006/exnr.2000.7426.

36. Kim HJ, McMillan E, Han F, Svendsen CN. Regionally specified human neural progenitor cells derived from the mesencephalon and forebrain undergo increased neurogenesis following overexpression of ASCL1. Stem Cells. 2009;27(2):390-8. doi:10.1634/stemcells.2007-1047.

37. Grimes DA, Han F, Panisset M, Racacho L, Xiao F, Zou R, et al. Translated mutation in the Nurr1 gene as a cause for Parkinson's disease. Mov Disord. 2006;21(7):906-9. doi:10.1002/mds.20820

38. Shim JW, Park CH, Bae YC, Bae JY, Chung S, Chang MY, et al. Generation of functional dopamine neurons from neural precursor cells isolated from the subventricular zone and white matter of the adult rat brain using Nurr1 overexpression. Stem Cells. 2007;25(5):1252-62. doi:10.1634/stemcells.2006-0274.

39. Bjorklund A, Dunnett SB, Stenevi U, Lewis ME, Iversen SD. Reinnervation of the denervated striatum by substantia nigra transplants: functional consequences as revealed by pharmacological and sensorimotor testing. Brain Res. 1980;199(2):307-33.

40. Studer L, Tabar V, McKay RD. Transplantation of expanded mesencephalic precursors leads to recovery in parkinsonian rats. Nat Neurosci. 1998;1(4):290-5. doi:10.1038/1105.

41. Monni E, Cusulin C, Cavallaro M, Lindvall O, Kokaia Z. Human fetal striatumderived neural stem (NS) cells differentiate to mature neurons in vitro and in vivo. Curr Stem Cell Res Ther. 2014;9(4):338-46.

42. Redmond Jr DE, Vinuela A, Kordower JH, Isacson O. Influence of cell preparation and target location on the behavioral recovery after striatal transplantation of fetal dopaminergic neurons in a primate model of Parkinson's disease. Neurobiol Dis. 2008;29(1):103-16. doi:10.1016/ j.nbd.2007.08.008.

43. Lindvall O, Brundin P, Widner H, Rehncrona S, Gustavii B, Frackowiak R, et al. Grafts of fetal dopamine neurons survive and improve motor function in Parkinson's disease. Science. 1990;247(4942):574-7.

44. Lindvall O, Sawle G, Widner H, Rothwell JC, Bjorklund A, Brooks D, et al. Evidence for long-term survival and function of dopaminergic grafts in progressive Parkinson's disease. Ann Neurol. 1994;35(2):172-80. doi:10.1002/ ana.410350208.

45. Freed CR, Greene PE, Breeze RE, Tsai WY, DuMouchel W, Kao R, et al. Transplantation of embryonic dopamine neurons for severe Parkinson's disease. N Engl J Med. 2001;344(10):710-9. doi:10.1056/NEJM200103083441002.

46. Lindvall O, Bjorklund A. Cell therapy in Parkinson's disease. NeuroRx 2004;1 (4):382-93. doi:10.1602/neurorx.1.4.382.

47. Barker RA, Barrett J, Mason SL, Bjorklund A. Fetal dopaminergic transplantation trials and the future of neural grafting in Parkinson's disease. Lancet Neurol. 2013;12(1):84-91. doi:10.1016/S1474-4422(12)70295-8.

48. Olanow CW, Goetz CG, Kordower JH, Stoessl AJ, Sossi V, Brin MF, et al. A double-blind controlled trial of bilateral fetal nigral transplantation in Parkinson's disease. Ann Neurol. 2003;54(3):403-14. doi:10.1002/ana.10720. 
49. Ma Y, Tang C, Chaly T, Greene P, Breeze R, Fahn S, et al. Dopamine cell implantation in Parkinson's disease: long-term clinical and (18)F-FDOPA PET outcomes. J Nucl Med. 2010;51(1):7-15. doi:10.2967/jnumed.109.066811.

50. Hagell P, Brundin P. Cell survival and clinical outcome following intrastriata transplantation in Parkinson disease. J Neuropathol Exp Neurol. 2001;60(8):741-52

51. Carlsson T, Carta M, Winkler C, Bjorklund A, Kirik D. Serotonin neuron transplants exacerbate L- DOPA-induced dyskinesias in a rat model of Parkinson's disease. J Neurosci. 2007;27(30):8011-22. doi:10.1523/ JNEUROSCI.2079-07.2007.

52. Politis M, Wu K, Loane C, Quinn NP, Brooks DJ, Rehncrona S, et al. Serotonergic neurons mediate dyskinesia side effects in Parkinson's patients with neural transplants. Sci Transl Med. 2010;2(38):38ra46. doi:10.1126/ scitranslmed.

53. Mendez I, Viñuela A, Astradsson A, Mukhida K, Hallett P, Robertson H, et al. Dopamine neurons implanted into people with Parkinson's disease survive without pathology for 14 years. Nat Med. 2008;14(5):507.

54. Li JY, Englund E, Holton JL, Soulet D, Hagell P, Lees AJ, et al. Lewy bodies in grafted neurons in subjects with Parkinson's disease suggest host-to-graft disease propagation. Nat Med. 2008;14(5):501-3. doi:10.1038/nm1746.

55. Kordower JH, Chu Y, Hauser RA, Freeman TB, Olanow CW. Lewy body-like pathology in long- term embryonic nigral transplants in Parkinson's disease. Nat Med. 2008;14(5):504-6. doi:10.1038/nm1747.

56. Nauta AJ, Westerhuis G, Kruisselbrink AB, Lurvink EG, Willemze R, Fibbe WE. Donor-derived mesenchymal stem cells are immunogenic in an allogeneic host and stimulate donor graft rejection in a nonmyeloablative setting Blood. 2006;108(6):2114-20. doi:10.1182/blood-2005-11-011650.

57. Michel-Monigadon D, Nerriere-Daguin V, Leveque X, Plat M, Venturi E, Brachet $P$, et al. Minocycline promotes long-term survival of neuronal transplant in the brain by inhibiting late microglial activation and T-cell recruitment. Transplantation. 2010;89(7):816-23. doi:10.1097/ TP.0b013e3181cbe041.

58. Moore SF, Guzman NV, Mason SL, Williams-Gray CH, Barker RA. Which patients with Parkinson's disease participate in clinical trials? One centre's experiences with a new cell based therapy trial (TRANSEURO). J Parkinsons Dis. 2014;4(4):671-6. doi:10.3233/JPD-140432

59. Evans JR, Mason SL, Barker RA. Current status of clinical trials of neural transplantation in Parkinson's disease. Prog Brain Res. 2012;200:169-98. doi:10.1016/B978-0-444-59575-1.00008-9.

60. Kefalopoulou Z, Politis M, Piccini P, Mencacci N, Bhatia K, Jahanshahi M, et al. Long-term clinical outcome of fetal cell transplantation for Parkinson disease: two case reports. JAMA Neurol. 2014;71(1):83-7. doi:10.1001/ jamaneurol.2013.4749.

61. Robertson EJ. Derivation and maintenance of embryonic stem cell cultures Methods Mol Biol. 1990;5:223-36. doi:10.1385/0-89603-150-0:223.

62. Trzaska KA, Rameshwar P. Dopaminergic neuronal differentiation protocol for human mesenchymal stem cells. Methods Mol Biol. 2011;698:295-303. doi:10.1007/978-1-60761-999-4_22.

63. Ganat YM, Calder EL, Kriks S, Nelander J, Tu EY, Jia F, et al. Identification of embryonic stem cell- derived midbrain dopaminergic neurons for engraftment. J Clin Invest. 2012;122(8):2928-39. doi:10.1172/JCI58767.

64. Liu TW, Ma ZG, Zhou Y, Xie JX. Transplantation of mouse CGR8 embryonic stem cells producing GDNF and TH protects against 6-hydroxydopamine neurotoxicity in the rat. Int J Biochem Cell Biol. 2013;45(7):1265-73. doi:10.1016/j.biocel.2013.03.011.

65. Thomson JA, Itskovitz-Eldor J, Shapiro SS, Waknitz MA, Swiergiel JJ, Marshall VS, et al. Embryonic stem cell lines derived from human blastocysts. Science. 1998;282(5391):1145-7.

66. Perrier AL, Tabar V, Barberi T, Rubio ME, Bruses J, Topf N, et al. Derivation of midbrain dopamine neurons from human embryonic stem cells. Proc Natl Acad Sci U S A. 2004;101(34):12543-8.

67. Zeng X, Cai J, Chen J, Luo Y, You ZB, Fotter E, et al. Dopaminergic differentiation of human embryonic stem cells. Stem Cells. 2004;22(6):925-40. doi:10.1634/stemcells.22-6-925

68. Ben-Hur T, Idelson M, Khaner H, Pera M, Reinhartz E, Itzik A, et al. Transplantation of human embryonic stem cell-derived neural progenitors improves behavioral deficit in Parkinsonian rats. Stem Cells. 2004;22(7):1246-55. doi:10.1634/stemcells.2004-0094.

69. Yan Y, Yang D, Zarnowska ED, Du Z, Werbel B, Valliere C, et al. Directed differentiation of dopaminergic neuronal subtypes from human embryonic stem cells. Stem Cells. 2005;23(6):781-90. doi:10.1634/stemcells.2004-0365.
70. Yang D, Zhang ZJ, Oldenburg M, Ayala M, Zhang SC. Human embryonic stem cell-derived dopaminergic neurons reverse functional deficit in parkinsonian rats. Stem Cells. 2008;26(1):55-63. doi:10.1634/stemcells.2007-0494.

71. Chambers SM, Fasano CA, Papapetrou EP, Tomishima M, Sadelain M, Studer L. Highly efficient neural conversion of human ES and iPS cells by dual inhibition of SMAD signaling. Nat Biotechnol. 2009;27(3):275-80. doi:10.1038/nbt.1529.

72. Fasano CA, Chambers SM, Lee G, Tomishima MJ, Studer L. Efficient derivation of functional floor plate tissue from human embryonic stem cells. Cell Stem Cell. 2010;6(4):336-47. doi:10.1016/j.stem.2010.03.001.

73. Kriks S, Shim JW, Piao J, Ganat YM, Wakeman DR, Xie Z, et al. Dopamine neurons derived from human ES cells efficiently engraft in animal models of Parkinson's disease. Nature. 2011;480(7378):547-51. doi:10.1038/nature10648.

74. Muramatsu S, Okuno T, Suzuki Y, Nakayama T, Kakiuchi T, Takino N, et al. Multitracer assessment of dopamine function after transplantation of embryonic stem cell-derived neural stem cells in a primate model of Parkinson's disease. Synapse. 2009;63(7):541-8. doi:10.1002/syn.20634.

75. Sanchez-Danes A, Consiglio A, Richaud Y, Rodriguez-Piza I, Dehay B, Edel M, et al. Efficient generation of A9 midbrain dopaminergic neurons by lentiviral delivery of LMX1A in human embryonic stem cells and induced pluripotent stem cells. Hum Gene Ther. 2012;23(1):56-69. doi:10.1089/hum.2011.054.

76. Grealish S, Diguet E, Kirkeby A, Mattsson B, Heuer A, Bramoulle Y, et al. Human ESC-derived dopamine neurons show similar preclinical efficacy and potency to fetal neurons when grafted in a rat model of Parkinson's disease. Cell Stem Cell. 2014;15(5):653-65. doi:10.1016/j.stem.2014.09.017.

77. Braam SR, Denning C, Matsa E, Young LE, Passier R, Mummery CL. Feederfree culture of human embryonic stem cells in conditioned medium for efficient genetic modification. Nat Protoc. 2008;3(9):1435-43. doi:10.1038/ nprot.2008.140.

78. Schulz TC, Noggle SA, Palmarini GM, Weiler DA, Lyons IG, Pensa KA, et al. Differentiation of human embryonic stem cells to dopaminergic neurons in serum-free suspension culture. Stem Cells. 2004;22(7):1218-38. doi:10.1634/ stemcells.2004-0114.

79. Vazin T, Becker KG, Chen J, Spivak CE, Lupica CR, Zhang Y, et al. A novel combination of factors, termed SPIE, which promotes dopaminergic neuron differentiation from human embryonic stem cells. PLoS One. 2009:4(8):e6606. doi:10.1371/journal.pone.0006606.

80. Swistowski A, Peng J, Han Y, Swistowska AM, Rao MS, Zeng X. Xeno-free defined conditions for culture of human embryonic stem cells, neural stem cells and dopaminergic neurons derived from them. PLoS One. 2009;4(7):e6233. doi:10.1371/journal.pone.0006233.

81. Wilmut I, Schnieke AE, McWhir J, Kind AJ, Campbell KH. Viable offspring derived from fetal and adult mammalian cells. Nature. 1997;385(6619):810-3. doi:10.1038/385810a0.

82. Colman A. Somatic cell nuclear transfer in mammals: progress and applications. Cloning. 1999;1(4):185-200. doi:10.1089/15204559950019825.

83. Jullien J, Pasque V, Halley-Stott RP, Miyamoto K, Gurdon JB. Mechanisms of nuclear reprogramming by eggs and oocytes: a deterministic process? Nat Rev Mol Cell Biol. 2011;12(7):453-9. doi:10.1038/nrm3140.

84. French AJ, Adams CA, Anderson LS, Kitchen JR, Hughes MR, Wood SH. Development of human cloned blastocysts following somatic cell nuclear transfer with adult fibroblasts. Stem Cells. 2008;26(2):485-93. doi:10.1634/stemcells.

85. Chung Y, Bishop CE, Treff NR, Walker SJ, Sandler VM, Becker S, et al. Reprogramming of human somatic cells using human and animal oocytes. Cloning Stem Cells. 2009;11(2):213-23. doi:10.1089/clo.2009.0004

86. Takahashi K, Yamanaka S. Induction of pluripotent stem cells from mouse embryonic and adult fibroblast cultures by defined factors. Cell. 2006;126(4):663-76. doi:10.1016/j.cell.2006.07.024.

87. Park $I H$, Zhao R, West JA, Yabuuchi A, Huo H, Ince TA, et al. Reprogramming of human somatic cells to pluripotency with defined factors. Nature. 2008;451(7175):141-6. doi:10.1038/nature06534.

88. Yu J, Vodyanik MA, Smuga-Otto K, Antosiewicz-Bourget J, Frane JL, Tian S, et al. Induced pluripotent stem cell lines derived from human somatic cells. Science. 2007:318(5858):1917-20. doi:10.1126/science.1151526.

89. Boyer LA, Lee TI, Cole MF, Johnstone SE, Levine SS, Zucker JP, et al. Core transcriptional regulatory circuitry in human embryonic stem cells. Cell. 2005;122(6):947-56. doi:10.1016/j.cell.2005.08.020.

90. Huangfu D, Osafune K, Maehr R, Guo W, Eijkelenboom A, Chen S, et al. Induction of pluripotent stem cells from primary human fibroblasts with only Oct4 and Sox2. Nat Biotechnol. 2008;26(11):1269-75. doi:10.1038/ nbt.1502. 
91. Li Y, Zhang Q, Yin X, Yang W, Du Y, Hou P, et al. Generation of iPSCs from mouse fibroblasts with a single gene, Oct4, and small molecules. Cell Res. 2011;21(1):196-204. doi:10.1038/cr.2010.142.

92. Isobe K, Cheng Z, Nishio N, Suganya T, Tanaka Y, Ito S. Reprint of "iPSCS, aging and age-related diseases". N Biotechnol. 2015;32(1):169-79. doi:10.1016/j.nbt.2014.11.002.

93. Kiskinis E, Eggan K. Progress toward the clinical application of patientspecific pluripotent stem cells. J Clin Invest. 2010;120(1):51-9. doi:10.1172/ $\mathrm{JCl} 40553$.

94. Zeng $X$, Couture LA. Pluripotent stem cells for Parkinson's disease: progress and challenges. Stem Cell Res Ther. 2013;4(2):25. doi:10.1186/scrt173.

95. Jung Y, Bauer G, Nolta JA. Concise review: Induced pluripotent stem cellderived mesenchymal stem cells: progress toward safe clinical products. Stem Cells. 2012;30(1):42-7. doi:10.1002/stem.727.

96. Saha K, Jaenisch R. Technical challenges in using human induced pluripotent stem cells to model disease. Cell Stem Cell. 2009;5(6):584-95.

97. Wernig M, Zhao J-P, Pruszak J, Hedlund E, Fu D, Soldner F, et al. Neurons derived from reprogrammed fibroblasts functionally integrate into the fetal brain and improve symptoms of rats with Parkinson's disease. Proc Natl Acad Sci. 2008;105(15):5856-61.

98. Hargus G, Cooper O, Deleidi M, Levy A, Lee K, Marlow E, et al. Differentiated Parkinson patient-derived induced pluripotent stem cells grow in the adult rodent brain and reduce motor asymmetry in Parkinsonian rats. Proc Natl Acad Sci U S A. 2010;107(36):15921-6. doi:10.1073/pnas.1010209107.

99. Sundberg M, Bogetofte H, Lawson T, Jansson J, Smith G, Astradsson A, et al. Improved cell therapy protocols for Parkinson's disease based on differentiation efficiency and safety of hESC-, hiPSC-, and non-human primate iPSC-derived dopaminergic neurons. Stem Cells. 2013;31(8):1548-62.

100. Ross CA, Akimov SS. Human-induced pluripotent stem cells: potential for neurodegenerative diseases. Hum Mol Genet. 2014;23(R1):R17-26. doi:10.1093/hmg/ddu204

101. Soldner F, Hockemeyer D, Beard C, Gao Q, Bell GW, Cook EG, et al. Parkinson's disease patient- derived induced pluripotent stem cells free of viral reprogramming factors. Cell. 2009;136(5):964-77. doi:10.1016/ j.cell.2009.02.013.

102. Nguyen HN, Byers $B$, Cord B, Shcheglovitov A, Byrne J, Gujar P, et al. LRRK2 mutant iPSC-derived DA neurons demonstrate increased susceptibility to oxidative stress. Cell Stem Cell. 2011:8(3):267-80. doi:10.1016/ j.stem.2011.01.013.

103. Reinhardt P, Schmid B, Burbulla LF, Schondorf DC, Wagner L, Glatza M, et al. Genetic correction of a LRRK2 mutation in human iPSCs links parkinsonian neurodegeneration to ERK-dependent changes in gene expression. Cell Stem Cell. 2013;12(3):354-67. doi:10.1016/j.stem.2013.01.008.

104. Emborg ME, Liu Y, Xi J, Zhang X, Yin Y, Lu J, et al. Induced pluripotent stem cell-derived neural cells survive and mature in the nonhuman primate brain. Cell Rep. 2013;3(3):646-50. doi:10.1016/j.celrep.2013.02.016.

105. Hallett PJ, Deleidi M, Astradsson A, Smith GA, Cooper O, Osborn TM, et al. Successful function of autologous iPSC-derived dopamine neurons following transplantation in a non-human primate model of Parkinson's disease. Cell Stem Cell. 2015;16(3):269-74. doi:10.1016/j.stem.2015.01.018.

106. Stadtfeld M, Nagaya M, Utikal J, Weir G, Hochedlinger K. Induced pluripotent stem cells generated without viral integration. Science. 2008;322(5903):945-9. doi:10.1126/science.1162494.

107. Okita K, Nakagawa M, Hyenjong H, Ichisaka T, Yamanaka S. Generation of mouse induced pluripotent stem cells without viral vectors. Science. 2008:322(5903):949-53. doi:10.1126/science.1164270.

108. Kaji K, Norrby K, Paca A, Mileikovsky M, Mohseni P, Woltjen K. Virus-free induction of pluripotency and subsequent excision of reprogramming factors. Nature. 2009;458(7239):771-5. doi:10.1038/nature07864.

109. Yu J, Hu K, Smuga-Otto K, Tian S, Stewart R, Slukvin II, et al. Human induced pluripotent stem cells free of vector and transgene sequences. Science. 2009;324(5928):797-801. doi:10.1126/science.1172482.

110. Kim D, Kim CH, Moon Jl, Chung YG, Chang MY, Han BS, et al. Generation of human induced pluripotent stem cells by direct delivery of reprogramming proteins. Cell Stem Cell. 2009;4(6):472-6. doi:10.1016/j.stem.2009.05.005

111. Rhee YH, Ko JY, Chang MY, Yi SH, Kim D, Kim CH, et al. Protein-based human iPS cells efficiently generate functional dopamine neurons and can treat a rat model of Parkinson disease. J Clin Invest. 2011;121(6):2326-35. doi:10.1172/JCl45794

112. Maherali N, Sridharan R, Xie W, Utikal J, Eminli S, Arnold K, et al. Directly reprogrammed fibroblasts show global epigenetic remodeling and widespread tissue contribution. Cell Stem Cell. 2007;1(1):55-70. doi:10.1016/ j.stem.2007.05.014.

113. Wernig M, Meissner A, Foreman R, Brambrink T, Ku M, Hochedlinger $K$, et al. In vitro reprogramming of fibroblasts into a pluripotent ES-cell-like state. Nature. 2007:448(7151):318-24. doi:10.1038/nature05944.

114. Nakagawa M, Koyanagi M, Tanabe K, Takahashi K, Ichisaka T, Aoi T, et al. Generation of induced pluripotent stem cells without Myc from mouse and human fibroblasts. Nat Biotechnol. 2008;26(1):101-6. doi:10.1038/nbt1374.

115. Muller LU, Daley GQ, Williams DA. Upping the ante: recent advances in direct reprogramming. Mol Ther. 2009;17(6):947-53. doi:10.1038/mt.2009.72.

116. Hu BY, Weick JP, Yu J, Ma LX, Zhang XQ, Thomson JA, et al. Neural differentiation of human induced pluripotent stem cells follows developmental principles but with variable potency. Proc Natl Acad Sci U S A. 2010;107(9):4335-40. doi:10.1073/pnas.0910012107.

117. Koyanagi-Aoi M, Ohnuki M, Takahashi K, Okita K, Noma H, Sawamura Y, et al. Differentiation- defective phenotypes revealed by large-scale analyses of human pluripotent stem cells. Proc Natl Acad Sci U S A. 2013;110(51):20569-74. doi:10.1073/pnas.1319061110.

118. Rodriguez-Piza I, Richaud-Patin Y, Vassena R, Gonzalez F, Barrero MJ, Veiga A, et al. Reprogramming of human fibroblasts to induced pluripotent stem cells under xeno-free conditions. Stem Cells. 2010;28(1):36-44. doi:10.1002/stem.248.

119. Chen VC, Couture SM, Ye J, Lin Z, Hua G, Huang HI, et al. Scalable GMP compliant suspension culture system for human ES cells. Stem Cell Res. 2012;8(3):388-402. doi:10.1016/j.scr.2012.02.001.

120. O'Brien C, Laslett AL. Suspended in culture-human pluripotent cells for scalable technologies. Stem Cell Res. 2012;9(2):167-70. doi:10.1016/ j.scr.2012.06.001.

121. Serra M, Brito C, Correia C, Alves PM. Process engineering of human pluripotent stem cells for clinical application. Trends Biotechnol. 2012;30(6):350-9. doi:10.1016/j.tibtech.2012.03.003.

122. Fang R, Liu K, Zhao Y, Li H, Zhu D, Du Y, et al. Generation of naive induced pluripotent stem cells from rhesus monkey fibroblasts. Cell Stem Cell. 2014;15(4):488-96. doi:10.1016/j.stem.2014.09.004.

123. Caiazzo M, Dell'Anno MT, Dvoretskova E, Lazarevic D, Taverna S, Leo D, et al. Direct generation of functional dopaminergic neurons from mouse and human fibroblasts. Nature. 2011:476(7359):224-7. doi:10.1038/nature10284.

124. Liu X, Li F, Stubblefield EA, Blanchard B, Richards TL, Larson GA, et al. Direct reprogramming of human fibroblasts into dopaminergic neuron-like cells. Cell Res. 2012;22(2):321-32. doi:10.1038/cr.2011.181.

125. Kim HS, Kim J, Jo Y, Jeon D, Cho YS. Direct lineage reprogramming of mouse fibroblasts to functional midbrain dopaminergic neuronal progenitors. Stem Cell Res. 2014;12(1):60-8. doi:10.1016/j.scr.2013.09.007.

126. Kim J, Su SC, Wang H, Cheng AW, Cassady JP, Lodato MA, et al. Functional integration of dopaminergic neurons directly converted from mouse fibroblasts. Cell Stem Cell. 2011;9(5):413-9. doi:10.1016/j.stem.2011.09.011.

127. Wang Q, Xu X, Li J, Liu J, Gu H, Zhang R, et al. Lithium, an anti-psychotic drug, greatly enhances the generation of induced pluripotent stem cells. Cell Res. 2011;21(10):1424-35. doi:10.1038/cr.2011.108.

128. Aoi T, Yae K, Nakagawa M, Ichisaka T, Okita K, Takahashi K, et al. Generation of pluripotent stem cells from adult mouse liver and stomach cells. Science. 2008;321(5889):699-702. doi:10.1126/science.1154884.

129. Aasen T, Raya A, Barrero MJ, Garreta E, Consiglio A, Gonzalez F, et al. Efficient and rapid generation of induced pluripotent stem cells from human keratinocytes. Nat Biotechnol. 2008;26(11):1276-84. doi:10.1038/ nbt.1503.

130. Kim K, Doi A, Wen B, Ng K, Zhao R, Cahan P, et al. Epigenetic memory in induced pluripotent stem cells. Nature. 2010;467(7313):285-90. doi:10.1038/ nature09342.

131. Lister R, Pelizzola M, Kida YS, Hawkins RD, Nery JR, Hon G, et al. Hotspots of aberrant epigenomic reprogramming in human induced pluripotent stem cells. Nature. 2011;471(7336):68-73. doi:10.1038/nature09798.

132. Hou P, Li Y, Zhang X, Liu C, Guan J, Li H, et al. Pluripotent stem cells induced from mouse somatic cells by small-molecule compounds. Science. 2013:341 (6146):651-4. doi:10.1126/science.1239278.

133. Mayshar Y, Ben-David U, Lavon N, Biancotti JC, Yakir B, Clark AT, et al. Identification and classification of chromosomal aberrations in human induced pluripotent stem cells. Cell Stem Cell. 2010;7(4):521-31. doi:10.1016/ j.stem.2010.07.017.

134. Gore A, Li Z, Fung HL, Young JE, Agarwal S, Antosiewicz-Bourget J, et al. Somatic coding mutations in human induced pluripotent stem cells. Nature. 2011;471(7336):63-7. doi:10.1038/nature09805. 
135. Laurent LC, Ulitsky I, Slavin I, Tran H, Schork A, Morey R, et al. Dynamic changes in the copy number of pluripotency and cell proliferation genes in human ESCs and iPSCs during reprogramming and time in culture. Cell Stem Cell. 2011;8(1):106-18. doi:10.1016/j.stem.2010.12.003.

136. Yu Z, Wang T, Xu J, Wang W, Wang G, Chen C, et al. Mutations in the glucocerebrosidase gene are responsible for Chinese patients with Parkinson's disease. J Hum Genet. 2015;60(2):85-90. doi:10.1038/ jhg.2014.110.

137. Soldner F, Laganiere J, Cheng AW, Hockemeyer D, Gao Q, Alagappan R, et al. Generation of isogenic pluripotent stem cells differing exclusively at two early onset Parkinson point mutations. Cell. 2011;146(2):318-31. doi:10.1016/ j.cell.2011.06.019.

138. Nakagawa M, Taniguchi Y, Senda S, Takizawa N, Ichisaka T, Asano K, et al. A novel efficient feeder-free culture system for the derivation of human induced pluripotent stem cells. Sci Rep. 2014;4:3594. doi:10.1038/srep03594.

\section{Submit your next manuscript to BioMed Central and take full advantage of:}

- Convenient online submission

- Thorough peer review

- No space constraints or color figure charges

- Immediate publication on acceptance

- Inclusion in PubMed, CAS, Scopus and Google Scholar

- Research which is freely available for redistribution 